Copyright (C) 2021 by Cherkas Global University

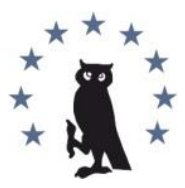

Published in the USA

Media Education (Mediaobrazovanie)

Has been issued since 2005

ISSN 1994-4160

E-ISSN 2729-8132

2021. 17(4): 623-631

DOI: $10.13187 / \mathrm{me} .2021 .4 .623$

https://me.cherkasgu.press

\title{
Conceptual Basis for Modeling the Phenomenon of "School Violence" in Modern Media Continuum of Russia and the United States of America
}

\author{
Olga Gorbatkova a, b,* \\ a Rostov State University of Economics, Russian Federation
}

\begin{abstract}
The article contains the conceptual basis for modeling the phenomenon of "school violence" in the retrospection of contemporary Russian and American audiovisual and printed/online texts that integrate violent content of different modificational variability.

As a result of solving of the set task, a model was developed on the subject of violence at school for the content of modern media texts in Russia and the United States of America (1992-2021). The model fundamental basis is a comparative analysis based on a hermeneutical approach to the interpretation of Russian and American media texts producing the content of "school violence" phenomenon construction. Model substantial elements: a historical concept that determines the period of media text creation; a socio-cultural concept, reflecting the influence of the situation in the social, cultural sphere of a particular country on the media text configuration; an ideological concept that integrates: the author's opinion and the ideological matrix of characters presented in the media texts; tools for depicting the reality: the main scene, genre palette, behavioral attitudes of the characters; the presented problem and ways to solve it.

It is indicated that the main conclusion as a result of the conceptual basis development for modeling the "school violence" phenomenon in the modern media continuum of Russia and the United States of America is that, despite the differences in the structure of the landscape of the countries mentality, in the ongoing configurations typical for the processes in the economic, political, socio-cultural segment, as a whole, the presented model smoothly fits into the common system of audiovisual and printed/online texts functioning on the subject of violence in the school environment at the present stage, of course, with a certain degree of convention. Moreover, the author concludes that the conceptual basis of the prevention and control system in the correlation of the projection of different violence constitutions in the educational environment of the school, both in Russia and in the United States, is reduced to a common conviction, typical for two countries, - today there is no effective prevention and counteraction mechanism. At the same time, significant fact for our research is that the paradigm in the context of solving the problem of school violence in the United States at the legislative level has the most effective experience, which is not typical for Russia.
\end{abstract} Russia.

Keywords: violence in school, media text, media continuum, substantial model, USA,

\section{Introduction}

The problem of school violence has recently been determined by the tendency to actualize the discourse field in the segment of the research focus at the global level.

\footnotetext{
${ }^{*}$ Corresponding author

E-mail addresses: gorbatkova1987@bk.ru (O. Gorbatkova)
} 
The expression of cruel actions, aggressive behavior of schoolchildren against peers, teachers today is a global problem, firmly taking the position of an established norm not only in Russia, but also in a number of Western countries.

Moreover, recently there has been a tendency towards shifting in the forms of violence expression and the degree of cruelty, aggressiveness, reflected in the "transition" from open bullying of classmates to armed attacks and murders in the educational institutions.

The scale of the school violence problem is illustrated in UNESCO report "Behind the numbers. Ending school violence and bullying" (2019). "Almost every third student (32 \%) at least once a month was subjected to various kinds of bullying by peers at school. The most common type of school violence in all regions except Europe and North America is physical violence, the second most common type is sexual violence. In Europe and North America, the psychological bullying is the most common type of abuse. At the same time, cyber-bullying affects every tenth child" (Behind..., 2019).

In the previously published results of our research work on the topic under consideration (Gorbatkova, 2020; Gorbatkova, Katrich, 2020) the content of the hermeneutic analysis of contemporary Russian and American audiovisual and printed/online texts on the subject of school violence was presented. Moreover, there were determined the substantial components of structural models, the landscape of the genre palette, techniques and tools for creating an image, and components of the stereotypical representation of Russian and American media commuting with interpretations of the problem of violence in the school environment.

\section{Materials and methods}

The material of our research is contemporary media texts from Russia and the USA, representing the phenomenology of the "school violence" concept, covering the time period from 1992 to 2021. The basic core of the research work is the implementation of a comparative hermeneutic analysis of the media space continuum in Russia and the United States in the practical segment, which recreates the ideological meaning of the school violence image.

\section{Discussion}

The comparison of the modern Russian and American media space demonstrates that the problem of school violence is in the focus of attention of the socio-cultural, educational landscape of the ecosystem, determining the level of growth of the phenomenon-in-question actualization in the content of scientific research field of the scientists.

It shall be noted that the largest contribution to the development of "violence" concept study in the educational space of school was made by the American scientists. Only in the field of studying the characteristics of the cinematographic works and television production impact on the younger generation "in the United States since 1920, about three thousand studies have been carried out" (Feilitzen, 2010: 175-176). At the same time, it is relevant to indicate that the research is of fragmentary nature, affecting only individual configurants of the "school violence" concept.

In general, the research of American scientists can be rather conditionally divided into the following areas in the context of the school violence problem study:

- violence and bullying among schoolchildren (Olweus, 1991; Roffey, 2000; Smith, Sharp, 1994 and others);

- violence in mass media (Berkowitz, 1962; Cannon, 1995; Gerbner, 2001; Hamilton, 2002 and others);

- connection between aggressive behavior and the reflection of violence forms in mass media (Lamson, 1995; Siano, 1995; Strasburger, 2009 and others);

- protection against violence in mass media (Peterson et al., 2001 and others);

- consequences of violence in mass media (Anderson, Bushman, 2002; 2017; Bushman, 2016; 2017; Bushman et al., 2015 and others);

- analysis of school life representation in American audiovisual media texts (Acland, 1995; Anderson et al., 2015; Anderson, Gentile, 2008; Ayers, 1994; Bauer, 1998; Burbach, Figgins, 1993; Cannon, 1995 ; Dalton, 2005; Trier, 2001 and others).

School violence has existed at all times, but with the development of technological progress, film industry, mass media and Internet the modern media space at this stage complicates and makes the problem even worse rather than helps to solve it. 
Recently, the representatives of the scientific community are concerned about several facts: firstly, the expression of cruelty and aggressiveness takes place not only in school environment, but is actively developing on the Internet (cyber-bullying); secondly, the peculiarities of broadcasting, reflection, specifics of comments, evaluations, methods of images creation by modern media agencies of violence subject in the educational space. Recently, the broadcast media content forms a certain informative image, which has a strong impact on the creation of the ideological matrix of a child/adolescent as the main behavioral factor, but at the same time, the media is not always of positive.

Free demonstration of cruelty in publicly available sources, most popular among the young people (Internet, social networks, television, etc.), acquiring the status of an established social model, can not only frighten with content, but also forms a model of social norms, provokes similar behavior. "Violence in mass media results in short-term increase of the existing aggressive scenarios and cognitive abilities, determining the increase of the physiological excitation and causing an automatic tendency to simulate the observed behavior. And also it leads to long-term consequences through the processes leading to the acquisition of stable (and automatically available) aggressive scenarios, interpretation schemes and beliefs about social behavior that support aggression, as well as by reducing the normal negative emotional responses of individuals towards violence (i.e. desensitization)" (Anderson et al., 2003).

In the Russian scientific and professional environment the subject of violence at school, in comparison with the development of American scientific research in this segment, has a shorter history of the formation and generation of the scientific basis of this problem, only starting from the 2000s, there has been a surge of interest from the scientists (Bykovskaya, 2006; Fedorov, 2003; 2004; Fedorov et al., 2019; Glazman, 2009; Krivtsova, 2011; Kutuzova, 2012; Kutyavina, Kuramshev, 2013; Malantseva, 2010; Mertsalova, 2000; Petrosyants, 2011; Potapov, 2016; Sudin, 2013; Vishnevskaya, Butovskaya, 2008; Volkova, Grishina, 2013 and others).

It should be noted that for more than 50 years the American scientists have been addressing the study of the phenomenon of "school violence" in various representative aspects. For the first time, the subject of studying the screen violence impact on the attitudes and patterns of behavior was touched upon by the American sociologists and psychologists back in the 1930s, but the conclusions obtained in the course of the research were criticized by the scientists of the Russian community. A little later, this subject was reflected in the scientific works of Russian researchers, however, we found a common characteristic feature for both countries - the the methodological basis has a number of significant disadvantages. Many aspects of the problem remain not properly studied, in particular, there is no common view of understanding the essence of "violence", "school violence"; specifics of personality traits of character of the participants in a situation of violence in the school environment (victim, aggressor); effective measures to prevent and control violence and cruel behavior of schoolchildren in the educational environment.

In this regard, many representatives of the American and Russian scientific research community are in an active search for the most effective ways and methods to solve the above problems within the framework of the research topic.

In addition, to the greatest extent, the objectives of the Russian scientists' scientific-research seeking are reduced to the consideration of the social space of the "violence in school" phenomenon, the influence of showing violent scenes content on the screen.

At the same time, American researchers position the scientific views in the focus of in-depth analysis of the constructs of the problem of media violence, determining effective ways to prevent and control violence in the school environment, integrating the media educational component into the educational institutions and improving the constructs of the violence struggle organization system within the walls of an educational institution in different variations at the legislative level.

\section{Results}

Analysis of Russian and American modern media content (1992-2021), reflecting the image of violence in the school environment, suggests that for a long time in Russia the problem of school violence was not reflected in reality, which cannot be said about the United States, where "a point of growth" of mass shootings within the walls of educational institutions falls on 1999 (mass shooting at Columbine School). Nevertheless, today, unfortunately, the demonstration of various forms of violence in Russian schools is sporadic. Together with that, in the last decade there has been a rapid increase in armed attacks by adolescents against students/teachers, which is typical 
not only for Russia, but also for the United States.

Audiovisual and printed/online texts typical of the modern period have occurred in view of our research: cinematographic works, TV shows, news content, printed/online mass media, Internet environment.

In the result of the comparative analysis we were able to find that modern Russian and American movies about school life are full of episodes of aggressive, cruel actions both from schoolchildren, who mock teachers, and among adolescents; intention or facts about the reasons for schoolchildren actions are the basic dominant of audiovisual media texts based on movie material related to school life.

The worldview of the authors of Russian and American cinematographic works is reduced to the fact that the author's position is one - a media product, the basic structure of which is the concept of "violence" of various configurations in the educational space of the school.

At that, we'd like to add that the problem of school violence is actively reflected in the TV programs, where there are clearly visible contextual references to the real sociocultural situation. Moreover, there is a tendency towards increased attention to the demonstration, discussion of scenes of brutal murders, hooligan blow-ups and cruel revenge. Most of the Russian and American television programs about school are focused on the physical and psychological challenges, violence, bullying, blackmailing, ruthlessness, aggression, etc.

Stereotypical methods of depicting the reality in American TV programs on the subject of violence in school are demonstrated as follows: for school audience - in negative structures, creating a situation of negative message broadcast; for different-age audience: storylines personify the relationship between students and teachers, which promote aggressive, cruel destructions, to a greater extent, against teachers.

Television also does not stand aside. Live broadcasts from the scene are supplemented with stories about victims of attacks, speeches of their relatives and nearest and dearest, politicians and officials, surviving peers, etc.

Events related to the demonstration of violent actions against schoolchildren/teachers, as a rule, ending tragically, find large resonance in printed/Internet versions of the mass media and cause heated debates about the need to take preventive measures, about the impact of the media space (cinema, TV shows, print publications, Internet, etc.) with violent content.

Analyzing the news content of printed/Internet mass media we found that the majority of the selected articles contained episodic reports, while the message was of an informative nature. Moreover, we succeeded to identify that the first case of mass shooting in Russian school was recorded on February 3, 2014 in Moscow, since that moment there has been an increase in cases of armed attacks on schools, accompanied by the murder of schoolchildren/teachers.

In 2018, the interest of not only scientists from different fields, but also representatives of public authorities in the development and integration of measures to prevent violence in schools is significantly increasing, in particular, strengthening of school activities in the direction of preventive work with adolescents; expanding the use of mass media for preventive purposes to prevent children's involvement in destructive/criminal activities; monitoring of social networks; building up the efforts in a law enforcement context.

However, in the United States, the first episode of mass shooting on school premises occurred in 1999 (Columbine School). As a result of our research, we found that in two decades following Columbine, there have been at least about 150 mass shootings in the United States, killing more than 950 people. In general, the mass media content is descriptive of the event.

Significant attention is paid in the direction of preventive work in the United States at the legislative level. Since 1999, certain measures have been introduced in the United States to struggle against bullying, aggressive persecution at school. A special public organization, Bully Police USA, is called upon to assess the quality of laws in this area, as well as to support victims of bullying. The federal government website, run by the US Department of Health and Human Services, is freely accessible and has useful links for both parents and children. At the same time, in this context, the Internet acts not only as a tool for broadcasting aggression, but also as a powerful information "tool" that can prevent this aggression or neutralize the consequences. There are also preventive programs created and consisting of schoolchildren, for example, the federal campaign among teenagers "Stop cyber-bullying". On Internet, on "YouTube" in particular, you can find numerous videos aimed at preventing violence in schools, telling about precautions in case of armed attack beginning. 
Taking into account all the above-mentioned aspects of the symbolic "conversion" of violence in the result of our previous studies (Gorbatkova, 2020; Gorbatkova, Katrich, 2020 and others) now we can turn to the review of substantial components of the model designed on the basis of the comparative analysis results based on a hermeneutic approach to the interpretation of mass media texts producing by the content of the "school violence" concept (refer to Fig. 1).

The fundamental basis of the substantial model of modern Russian and American media texts (1992-2021) was made up of:

1. Historical concept that determines the period of media text creation and the country: the contemporary stage of media text creation (1992-2021); Russia and the USA.

2. Sociocultural context reflecting the influence of the situation, which occurred in the social, cultural sphere of a particular country, on the configuration of the media text: at the turn of the 9os of the 2oth century, after the abolition of censorship in the media continuum of Russia, content containing a violent nature began to be actively displayed, which became a priority formula of a media image creation in subsequent years. Since 1992, Russian media texts have undergone substantial, quantitative and genre modifications. A specific feature is the integration of foreign media production, as a rule, integrating demonstrative and spectacular images of violence.

At the same time, one of the main events in the cultural and historical aspect of the United States is the tragedy at Columbine School (mass shooting), which played a decisive role in the formation of school shooting in the United States and became the reason for many similar incidents. Moreover, we have identified a clear relationship between the demonstration of violent actions by schoolchildren and an event that took place in the United States in 1999 - the mass shooting at Columbine School. Wide broadcast by various media channels (cinema, printed publications, Internet, television) of this event served as a kind of "impetus" for organizing a wide range of followers not only in foreign countries, but also in Russia.

3. Worldview concept that integrates:

a) Author's opinion in media texts - a product in the form of an audiovisual, printed/Internet version of the mass media containing naturalistic content of a violent nature in the context of the educational space functioning at school.

b) Worldview matrix of characters presented in media texts (inner world, value and behavioral attitudes) - schoolchildren/teachers with purposeful/unintentional inhuman manifestations; the appearance is strongly pronounced, sometimes imitative; the prevailing vocabulary (among schoolchildren) is rough.

Among adolescents one can identify: leaders and heroes demonstrating conformism; energetic, mobile and inflexible (adolescents who have difficulties in adapting to the ongoing changes in the surrounding environment); extroverts open to communication and introverts (closed); - physical appearance is the most common cause of bullying.

The value dominants of the main characters - schoolchildren (aggressors) are anger, hatred, ruthlessness, aggression, ferocity, merciless cruelty.

4. Tools for depicting reality: the main scene, genre palette, stereotyped techniques.

The main area, where the tragic events take place is the school territory, which includes classes, school corridors.

The genre palette is reduced to the dominance of the violence image in: thrillers, horrors, drama; TV talk shows, TV programs; reports, interviews, notes, messages-chronicles.

The stereotypical image recreated by the media texts authors:

- "Plot stereotypes" concept: stereotyped storyline (introduction, development of events, culmination, apotheosis); scene of action, number of main characters, appearance, value-based orientations, behavioral reactions;

- "Communicative stereotypes" concept: verbal stereotypes (linguistic peculiarities of the schoolchildren/teachers' speech); non-verbal stereotypes (description of school violence between teenagers in movies, demonstration of cruelty, aggression, attacks on teachers, demonstration of the lifestyle and behavior patterns of adolescents).

5. Presented problem: threat to the health and life of schoolchildren/teachers, in particular, as a result of armed attacks; a pupil is an object of bullying, harassment, aggressive persecution, in particular with the use of electronic devices, getting into a situation of expropriation.

The range of reasons for the implementation of violent actions is determined by the presence of conflict situations in the school team, in relations with the teacher; unrequited love; a desire to prove one's own worth in the class; interest in the Columbine movement. 
Purpose - comparative hermeneutic analysis of modern media texts of Russia and the United States representing the phenomenology of the "school violence" concept covering the time period from 1992 to 2021

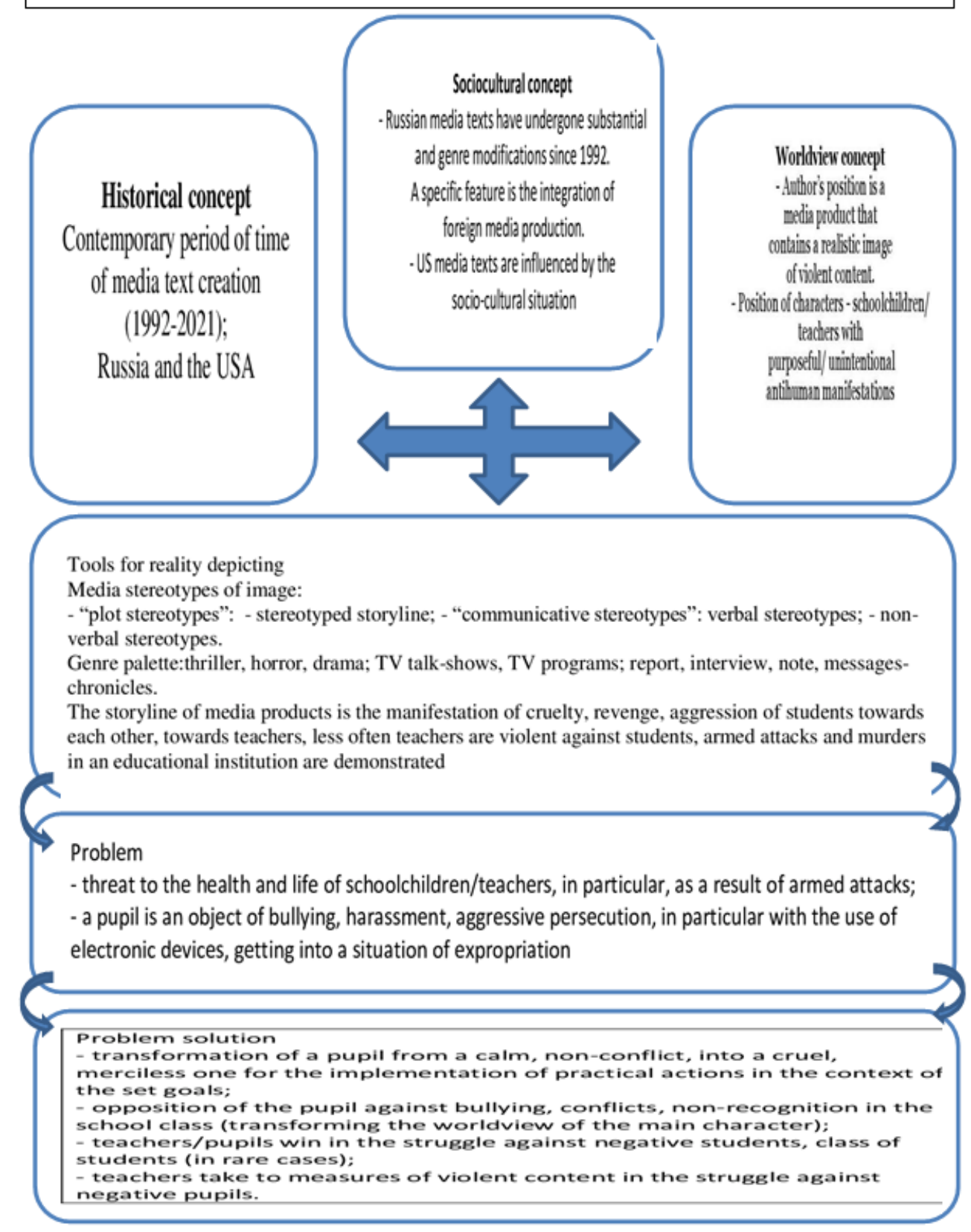

Fig. 1. Model of content of modern media continuum of Russia and the United States in the configuration of "school violence" concept

\section{Ways of solving the problem:}

- transformation of a pupil from a calm, non-conflict, into a cruel, merciless one for the implementation of practical actions in the context of the set goals;

- opposition of the pupil against bullying, conflicts, non-recognition in the school class (transforming the worldview of the main character); cases);

- teachers/pupils win in the struggle against negative students, class of students (in rare

- teachers take to measures of violent content in the struggle against negative pupils.

\section{Conclusion}

The main conclusion as a result of the development of conceptual foundations for "school violence" phenomenon modeling in the modern media continuum of Russia and the United States 
is that, despite the differences in the landscape structure of the countries mentality, in the ongoing configurations typical for the processes in the economic, political, sociocultural segment, in general, the presented model organically fits into the overall system of audiovisual and printed/online texts functioning on the subject of violence in the school environment at the contemporary stage, of course, with a certain degree of convention.

In addition, the author has determined that the conceptual basis of the prevention and control system in the correlation of the projection of different violence constitutions in the educational environment of the school, both in Russia and in the United States, is reduced to a common conviction, typical for two countries, - today there is no effective prevention and counteraction mechanism. At the same time, significant fact for our research is that the paradigm in the context of solving the problem of school violence in the United States at the legislative level has the most effective experience, which is not typical for Russia.

Already in 1999, the United States began to fight against bullying at the legislative level, as evidenced by the adoption in all American states (and there are 50 of them) of legislation on struggling against bullying in the school environment. The last state, which implemented the law, was Montana (April 2015). However, at the present moment, the question of establishing a specific act on the prohibition of bullying at the federal level is not yet available, though, some attempts in this direction have been made.

As part of our research, we found that the problem of violence against teachers is very rarely discussed, with the exception of some incidents that are widely spread in the mass media. In American public schools, the reality of violence against teachers is a real threat to many, who work in the education system. However, there is very little research in this area, both in Russia and in the United States. Currently, there is a lack of scientific research on the detailed descriptions of the types of violence faced by teachers; moreover, the individual, classroom, school, institutional and cultural factors that are predictors of the violence prevalence against teachers have not been comprehensively investigated.

In addition, there is a lack of scientific research concerning: a clear understanding of the essence of "violence", "school violence"; specifics of personality traits of participants in a situation of violence in the school environment (victim, aggressor); effective measures to prevent and struggle against violence and cruel behavior of schoolchildren in the educational environment.

\section{Acknowledgments}

The article is written as part of a study funded by the grant of the President of the Russian Federation for state support of young scientists - Ph.D. Project MK -1716.2020.6 "Problem of school violence in the mirror of modern Russian and American media: comparative analysis", carried out at the Rostov State University of Economics.

\section{References}

Acland, 1995 - Acland, C. (1995). Youth, murder, spectacle. the cultural politics of youth in crisis. Boulder: Westview Press, 1995. 176 p.

Anderson et al., 2003 - Anderson, C A., Berkowitz, L., Donnerstein, E., Huesmann, L.R., Johnson, J. D., Linz, D., Malamuth, N.M., Wartella, E. (2003). The influence of media violence on youth. Psychological science in the public interest. 4(3): 81-110. [Electronic resource]. URL: http://hdl.handle.net/2027.42/83429 DOI:10.1111/j.1529-1006.2003

Anderson et al., 2015 - Anderson, C.A, Andrighetto, L., Bartholow, B.D., Bègue, L., Boxer, P. (2015). Consensus on media violence effects: comment on Bushman, Gollwitzer, and Cruz. Psychol Pop Media Cult. 4(3): 215-221.

Anderson et al., 2017 - Anderson, C.A., Bushman, B. J., Bartholow, B.D., Cantor, J. (2017). Screen violence and youth behavior. Pediatrics. 14O(1): 142-149. DOI: 10.1542/peds.2016-1758T

Anderson, Bushman, 2002 - Anderson, C.A., Bushman, B.J. (2002). The effects of media violence on society. Science. 295.

Anderson, Gentile, 2008 - Anderson, C.A., Gentile, D.A. (2008). Violence in the media, aggression, and public policy. Beyond common sense: Psychological science in the courtroom: 281-300.

Ayers, 1994 - Ayers, W. (1994). A Teacher ain't nothin' but a hero: teachers and teaching in film. In: Joseph, P., Burnaford, G. (eds.). Images of schoolteachers in twentieth-century America. New York: St. Martin's Press, 1994: 147-156. 
Bauer, 1998 - Bauer, D.M. (1998). Indecent proposals: teachers in the movies. College English. 60(3): 301-317.

Behind..., 2019 - Behind the numbers. Ending school violence and bullying. UNESCO (2019). [Electronic resource]. URL: http://www.unesco. org/open-access/terms-use-ccbysa-en)

Berkowitz, 1962 - Berkowitz, L. (1962). Violence in the mass media. In: Berkowitz, L. (ed.). Aggression: A social psychological analysis. New York: McGraw-Hill: 229-255.

Burbach, Figgins, 1993 - Burbach H.J., Figgins M.A. (1993). A thematic profile of the images of teachers in film. Teacher Education Quarterly. 20(2): 65-75.

Bushman et al., 2015 - Bushman, B.J., Gollwitzer, M., Cruz, C. (2015). There is broad consensus: media researchers agree that violent media increase aggression in children, and pediatricians and parents concur. Psychol Pop Media Cult. 4(3): 200-214.

Bushman, 2016 - Bushman, B.J. (2016). Violent media and hostile appraisals: a metaanalytic review. Aggress Behav. 42(6): 605-613.

Bushman, 2017 - Bushman, B.J. (2017). Aggression and violence: A social psychological perspective. New York: Routledge.

Bykovskaya, 2006 - Bykovskaya, E.F. (2006). Pedagogicheskoe nasilie: teoriya i praktika [Pedagogical violence: theory and practice]. Filosofiya obrazovaniya - Philosophy of Education. 1: 221-229. [in Russian]

Cannon, 1995 - Cannon, C. (1995). Media violence increases violence in society. In: Wekesser, C. (ed.). Violence in the Media. San Diego, CA: Greenhaven Press: 17-24.

Dalton, 2005 - Dalton, M.M. (2005). Our Miss Brooks: Situating gender in teacher sitcoms. In: Dalton, M.M., Linder, L.R. (eds.). The sitcom reader: America viewed and skewed. Albany: State University of New York Press: 99-109.

Fedorov et al., 2019 - Fedorov, A.V., Levitskaya, A.A., Chelysheva, I.V., Gorbatkova, O.I., Mikhaleva, G.V., Seliverstova, L.N. School and university in the mirror of American, British, French, German and Russian movies. Moscow: ICO Information for All, 2019. $232 \mathrm{p}$.

Fedorov, 2003 - Fedorov, A. (2003). Violence on the Russian \& American Media Screen and Youth Audience. Taganrog: Kuchma.

Fedorov, 2004 - Fedorov, A. (2004). Prava rebenka i problema nasiliya na rossijskom ekrane [Children's Rights and Problem of Violence on the Russian Screen]. Taganrog. [in Russian]

Feilitzen, 2010 - von Feilitzen, C. (2010). Influences of mediated violence. Children and Youth in the Digital Media Culture. Yearbook. From a Nordic Horizon. Nordicom University of Göteborg: 175-176.

Gerbner, 2001 - Gerbner, G. (2001). communities should have more control over the content of mass media. In: Torr, J.D. (ed.). Violence in the Media. San Diego, CA: Greenhaven Press: 129-137.

Glazman, 2009 - Glazman, O.L. (2009). Psikhologicheskie osobennosti uchastnikov bullinga [Psychological features of participants in bullying]. Izvestiya Rossïskogo gosudarstvennogo pedagogicheskogo universiteta im. A.I. Gertsena. 105: 159-165. [in Russian]

Gorbatkova, 2020 - Gorbatkova, O. (2020). Phenomenology of school violence in the continuum of contemporary print and electronic media texts in Russia. Media Education. 60(4): 597-608. DOI: 10.13187/me.2020.4.597

Gorbatkova, 2020 - Gorbatkova, O., Katrich, A. (2020). Representation of the concept "school violence" in the mirror of contemporary American cinema (1992-2020). Media Education. 6o(3): 375-385. DOI: 10.13187/me.2020.3.375

Hamilton, 2002 - Hamilton, J.T. (2002). Violence on television is a serious problem. In: Torr, J.D. (ed.). Is Media Violence a Problem? San Diego, CA: Greenhaven Press: 18-21.

Krivtsova, 2011 - Krivtsova, S.V. (2011). Bulling v shkole vs splochennost' neravnodushnykh [School bullying vs solidarity of non-indifferent people]. Moscow. [in Russian]

Kutuzova, 2012 - Kutuzova, D.A. (2012). Problema travli detey v shkole [Bullying problem at school]. [Electronic resource]. URL: http://pro-psixology.ru/prakticheskaya-psixologiya-nauchnom etodicheskij/1094-problema-travli-detej-v-shkole-obzor-zarubezhnyx.html [in Russian]

Kutyavina, 2013 - Kutyavina, Ye.Ye., Kuramshev, A.M. (2013). Problema nasiliya v shkole glazami uchiteley [School violence through the eyes of teachers]. Vestnik Nizhegorodskogo gosuniversiteta im. N.I. Lobachevskogo. 3(31): 45-51. [in Russian]

Lamson, 1995 - Lamson, S.R. (1995). Media violence has increased the murder rate. In Wekesser, C. (ed.). Violence in the Media. San Diego, CA: Greenhaven Press: 25-27.

Malantseva, 2010 - Malantseva, O., (2010). Nasiliye v shkole: puti resheniya problemy 
[School violence: ways to solve the problem]. Sotsial'naya pedagogika. 2: 113-116. [in Russian]

Mertsalova, 2000 - Mertsalova, T.A. (2020). Nasiliye v shkole: chto protivopostavit' zhestokosti i agressii? [Violence in school: how to oppose cruelty and aggression?]. Direktor shkoly. 3: 25-32. [in Russian]

Olweus, 1991 - Olweus, D. (1991). Bully-victim problems among school children: Basic facts and effects of a school-based intervention program. In Rubin, K., Pepler, D. (eds.). The development and treatment of childhood aggression. Hillsdale, NJ: Erlbaum: 85-128.

Peterson et al., 2001 - Peterson, R.L., Larson, J., Skiba, R. (2001). School violence prevention: Current status and policy recommendations. Law and Policy. 23: 345-371.

Petrosyants, 2011 - Petrosyants, V.P. (2011). Problema bullinga v sovremennoy obrazovatel'noy srede [Bullying problem in the modern educational environment]. Vestnik Tomskogo gosudarstvennogo pedagogicheskogo universiteta. 6: 151-154. [in Russian]

Potapova, 2016 - Potapova, L.V. (2016). Nasilie v shkole kak sotsial'naya problema [Violence at school as a social problem]. Tavricheskii nauchnyi obozrevatel'. 6(11): 47-54. [in Russian]

Roffey, 2000 - Roffey, S. (2000). Addressing bully in schools: organisational factors from policy to practice. Educational and Child Psychology. 7 (1): 6-19.

Siano, 1995 - Siano, B. (1995). Evidence connecting media violence to real violence is weak. In: Wekesser, C. (ed.). Violence in the Media. San Diego, CA: Greenhaven Press: 38-48.

Smith, Sharp, 1994 - Smith, P.K., Sharp, S. (1994). The problem of school bullying. In: Smith, P.K., Sharp, S. (eds.). School bullying: insights and perspectives. London: Routledge.

Strasburger, 2009 - Strasburger, V.C. (2009). Policy statement - media violence. American academy of pediatrics. 124(5): 1495-1503.

Sudin, 2013 - Sudin, S.A. (2013). Psikhicheskoye zdorov'ye kak faktor shkol'nogo nasiliya v Rossii i SSHA [Mental health as a factor of school violence in Russia and the United States]. Vestnik Nizhegorodskogo universiteta im. N.I. Lobachevskogo - Bulletin of the Nizhny Novgorod University named after N.I. Lobachevsky. 4(32): 100-104. [in Russian]

Trier, 2001 - Trier, J.D. (2001). The cinematic representation of the personal and professional lives of teachers. Teacher Education Quarterly. 28(3): 127-142.

Vishnevskaya, Butovskaya, 2008 - Vishnevskaya, V.I., Butovskaya, M.L. (2008). Shkol'naya travlya $\mathrm{v}$ vospominaniyakh studentov moskovskikh vuzov [School bullying in the memoirs of Moscow University students. Young muscovites: Cross-cultural research]. Moscow. [in Russian]

Volkova, Grishina, 2013 - Volkova E.N., Grishina A.V. (2013). Otsenka rasprostranennosti nasiliya v obrazovatel'noi srede shkoly [Estimation of the violence expansion in the educational environment of a school]. Psikhologicheskaya nauka i obrazovanie. 18(6): 19-28. [in Russian] 